\title{
Dallas Conference Report
}

Dallas greeted us with a blazing Texas sun, a new convention center, several spectacular hotels, and a conference schedule crammed with activities. We had everything at Dallas except the time to do everything.

The Rare Books and Manuscripts Section led off ACRL activity down in San Antonio, Texas, with a preconference that attracted 190 persons The preconference featured papers (on topics such as creating an OCLC record for the Gutenberg Bible or buying "sleepers" at the London auction galleries) and offered five informal workshops. The social activity culminated in a cocktail party at the Alamo.

Back in Dallas, the Bibliographic Instruction Section drew 225 people to the campus of Southern Methodist University for a three-day preconference on library instruction. Participants received room, board, and participation in a workshop of their choice (six were offered) for the bargain cost of seventy dollars

At the Hyatt Regency Hotel (a crystal palace), fifty-nine people attended the Continuing Education Committee's first preconference (on workshop planning). Thus encouraged, the committee is looking forward to holding a second preconference next year on staff development.

At the ALA Conference itself, the big news was council's decision to increase dues to fifty dollars (subject to membership approval by a mail vote)

From the ACRL Board came the announcement that Jay Poole of the University of Texas at Austin Libraries had been selected as the editor of Choice. And at a special reception given by the Baker \& Taylor Company, Henriette Avram and Frederick Kilgour were named corecipients of the second ACRL Academic/Research Librarian of the Year Award.

Two Dallas events drew ACRL members in throngs. One was the Saturday night music and dancing at the conference reception at the Dallas City Plaza. Undeterred by the ninety-degree heat, hundreds of academic librarians danced to the music of the Lone Star Express. While the music and free refreshments inspired the gyrations of the dancers, a helicopter hovered overhead in the night sky. It blinked out the message that Dallas was available as the future home of the National Periodicals Center.

In the cooler atmosphere of the Fairmont Hotel on Monday afternoon, 750 people crowded into the ACRL Program Meeting to hear sociologist Hugh Cline and psychologist Loraine Sinnott talk about their use of social science techniques to study collection development activities at seven academic libraries. At the conclusion of the program, the crowd moved on to the
ACRL reception to enjoy an impressive spread of food and drink provided by Carrollton Press. Among the luminaries of the profession present were Daniel Boorstin and Quincy Mumford

The Community and Junior College Libraries Section held one of the nearly twenty ACRL program events sponsored by ACRL sections, committees, and discussion groups at Dallas. The community college librarians put on a day of activity that included a talk by Dr. John Roueche on the needs of users, a presentation on grants applications, discussion sessions, and a dinner at the Sheraton Dallas.

If you weren't with us at Dallas, please put it on your agenda to join us next year in New York.

Editor's note: Terry Belanger, Joleen Bock, and Carolyn Dusenbury kindly submitted news for this article.

\section{RLG HAS FOUR NEW MEMBERS}

Four universities joined the Research Libraries Group (RLG) of Stanford, California, during the summer. The four are Brigham Young. Dartmouth, Rutgers, and the University of Iowa With these additions, the total membership of the consortium now stands at eleven.

In June RLG received $\$ 600,000$ in foundation grants. The Charles A. Dana Foundation of Greenwich, Connecticut, and the William and Flora Hewlett Foundation of Palo Alto, California, each awarded $\$ 300,000$ to RLG to help support the expansion of its computerized bibliographic system. These gifts bring the total in grant support received by RLG since the beginning of the year to $\$ 2,600,000$.

\section{LIBRARIANS BARGAIN WITH BOSTON UNIVERSITY}

At Boston University, librarians represented by the Service Employees International Union began contract negotiations with the university this summer. A year ago, twenty Boston University librarians elected Local 925 of the Service Employees to represent them. The university agreed to bargain with the local in April of 1979, but has continued to press a lawsuit claiming that the librarians' bargaining unit is inappropriate. 